\title{
Variations of Learning Methods as Implementation of Teacher's Pedagogical Knowledge
}

\author{
Rosa Diah Shinvani*, Dwita Kurnia Amalia, Rindiana Evitaloka, Fery Anggara Putra, \& \\ Ifit Novita Sari
}

Universitas Islam Malang, Jl. MT Haryono No. 193, Malang 65144, Indonesia

\begin{abstract}
The development of student potential can be realized through the role of teachers in the use of learning methods during the teaching and learning process. Learning methods are expected to run well during the teaching and learning process. Therefore, the teacher must be able to determine the right method of learning. Teachers must have the ability to manage learning. This ability is one part of a teacher's pedagogical competence. If a teacher has qualified pedagogical competencies, then the use of learning methods selected during the teaching and learning process certainly provides positive results for students in learning. This research aims to find out the learning methods that are often applied by teachers based on pedagogical competencies owned and subjects that are mastered. The research method used is a descriptive qualitative method, with data collection techniques using google form spread surveys. From the results of data processing, it can be known that the most dominant learning method used by teachers is the discussion method. The reason teachers choose the discussion method is to prioritize interaction between students. So that from the method of discussion learning, it is expected to stimulate the thinking power of students to dare to express their opinions.
\end{abstract}

Keywords: Teacher, pedagogical khowledge, learning method.

\section{Introduction}

Seorang guru yang profesional, harus memiliki kemampuan atau keahlian khusus dan dituntut untuk bisa melaksanakan perannya secara maksimal. Tugas guru tidak hanya mengajar, melatih, tapi juga mendidik. Guru merupakan seorang pembina, pendidik, dan pengajar yang dibekali dengan pengetahuan tentang anak didik, dan memiliki kemampuan untuk melaksanakan tugas kependidikan. Guru yang dikenal dengan sebutan pendidik atau pengajar ialah seorang pendidik profesional yang memiliki tugas penting yaitu mengajar, mendidik, mengarahkan, membimbing, melatih, menilai, dan mengevaluasi siswa dalam beberapa jalur pendidikan yaitu pendidikan anak, pendidikan formal, pendidikan dasar, dan pendidikan menengah (Sumarsono et al., 2021).

Guru yang kompeten berarti harus memiliki empat kompetensi dasar yaitu kompetensi pedagogik, kompetensi kepribadian, kompetensi sosial, dan kompetensi profesional. Kompetensi pedagogik merupakan salah satu kompetensi yang dijadikan sebagai dasar dalam mengemban tugas dan kewajiban seorang guru. Kompetensi pedagogik yang dimiliki oleh setiap guru berkaitan erat dengan penggunaan metode pembelajaran. Kompetensi pedagogik berhubungan dengan pemahaman siswa dan pengelolaan pembelajaran yang mendidik dan komunikatif (Sari, 2020).

Kompetensi pedagogik adalah kemampuan yang harus dimiliki guru dalam mengelola pembelajaran termasuk kesiapan mengajar yang ditampilkan melalui penguasaan dan keterampilan mengajar (Wibowo, 2012). Pasal 28 ayat (3) dalam Standar Nasional Pendidikan dijelaskan bahwa kompetensi pedagogik, yaitu kemampuan mengelola pembelajaran siswa yang meliputi pemahaman terhadap siswa, perancangan dan pelaksanaan pembelajaran, evaluasi hasil belajar, dan pengembangan siswa untuk mengaktualisasikan berbagai potensi yang dimilikinya. Oleh karena itu, apabila seorang guru memiliki kompetensi pedagogik yang berkualitas, maka penggunaan metode pembelajaran yang dipilih saat proses belajar mengajar pasti memberikan dampak yang positif bagi siswa dalam belajar. Proses mengembangkan potensi diri siswa di sekolah dapat diwujudkan melalui peran guru dalam penggunaan metode

\footnotetext{
* Corresponding author.

E-mail address: rosadiahshinvani9@gmail.com (Rosa Diah Shinvani)
} 
pembelajaran saat proses belajar mengajar. Dalam proses pembelajaran, metode yang digunakan guru harus sistematis untuk menghasilkan capaian pembelajaran yang maksimal.

Metode pembelajaran adalah cara yang digunakan guru dalam menjalin hubungan dengan siswa pada saat berlangsungnya kegiatan pengajaran dalam upaya untuk mencapai tujuan (Aditya, 2016). Adanya metode pembelajaran ini ditujukan agar kegiatan belajar dapat berlangsung secara efektif dan efisien. Oleh karena itu, tugas wajib seorang pendidik ketika mengajar yaitu menentukan metode pembelajaran yang akan digunakan saat kegiatan belajar mengajar agar semangat siswa semakin meningkat. Beberapa metode pembelajaran yang dapat digunakan oleh guru dalam proses belajar mengajar antara lain: metode ceramah, diskusi, latihan (drill), dan kooperatif jigsaw.

Pertama, metode ceramah adalah metode pembelajaran yang penyampaian materinya secara lisan. Metode ini merupakan salah satu metode yang gemar digunakan oleh seorang guru. Dalam metode ini, guru akan menjalankan perannya sebagai pendidik yaitu menyampaikan materi pembelajaran kepada siswa, dengan proses penuturan secara lisan atau penerangan (Pratiwi, 2021). Dalam metode ceramah, ucapan seorang guru menjadi hal yang utama. Seorang guru yang menggunakan metode pembelajaran ceramah harus memiliki vokal yang jelas, agar siswa mengerti dengan penyampaian materi yang dilakukan guru. Metode ini sangat cocok digunakan dalam pembelajaran dengan massa yang banyak. Dengan metode ini, guru dapat menyampaikan materi dengan sangat mudah dan proses pembelajaran berjalan dengan efektif.

Kedua, metode diskusi merupakan suatu metode pembelajaran yang memberikan siswa kesempatan untuk mengadakan perbincangan atau pembahasan ilmiah agar dapat menyusun alternatif pemecahan suatu masalah dan kesimpulan (Junita \& Siregar, 2018). Metode diskusi menjalin interaksi antara siswa menjadi poin utama, dan metode ini berfungsi untuk merangsang daya pikir siswa saat kegiatan diskusi berlangsung.

Ketiga, metode latihan (drill) merupakan suatu teknik mengajar dimana siswa melaksanakan kegiatan latihan, sehingga siswa memiliki ketangkasan atau keterampilan yang lebih tinggi dari apa yang telah dipelajari (Rusman \& $\mathrm{Pd}$, 2012). Metode latihan bertujuan untuk memperoleh suatu ketangkasan, keterampilan tentang sesuatu yang dipelajari oleh siswa.

Keempat, metode kooperatif jigsaw merupakan model pembelajaran kooperatif jigsaw adalah model pembelajaran yang mampu mengajari siswa dengan pendekatan struktur serta meningkatkan keterampilan sosial dalam berbagai kelompok. Model pembelajaran kooperatif jigsaw merupakan salah satu model pembelajaran yang mendorong siswa aktif dan saling membantu dalam menguasai materi pelajaran untuk mencapai prestasi yang maksimal (Isjoni, 2014).

Dari keempat jenis tersebut, pemilihan metode pembelajaran yang dilakukan oleh guru dapat menentukan kompetensi pedagogik yang dimilikinya. Pemilihan metode pembelajaran ini, tentunya harus disesuaikan dengan mata pelajaran atau materi pembelajaran yang akan diajarkan. Harapannya, proses pembelajaran dapat terlaksana secara maksimal apabila kompetensi pedagogik guru (pemilihan metode pembelajaran) sesuai dengan mata pelajaran atau materi pembelajaran yang akan diajarkan.

Nasution (2018) meneliti tentang penggunaan metode pembelajaran yang berjudul Penggunaan Metode Pembelajaran dalam Peningkatan Hasil Belajar Siswa (Nasution, 2018). Penelitian ini dilakukan dengan tujuan untuk memahami dan menganalisis penggunaan metode pembelajaran yang meningkatkan hasil belajar siswa di sekolah, peningkatan prestasi atau hasil belajar siswa menjadi tujuan utama dalam proses pembelajaran di sekolah.

Berdasarkan uraian di atas, penelitian ini berfokus pada penggunaan metode pembelajaran berdasarkan kompetensi pedagogik yang dimiliki guru Sekolah Menengah Atas (SMA), Madrasah Aliyah (MA), Sekolah Menengah Kejuruan (SMK) di empat daerah yaitu Gresik, Pasuruan, Malang, Jombang, dan Bojonegoro. Peneliti ingin mengetahui, mengidentifikasi, dan menganalisis bagaimana penggunaan metode pembelajaran yang dipilih guru berdasarkan kompetensi pedagogik yang dimilikinya. Penelitian ini mencoba mendeskripsikan bagaimana penggunaan metode pembelajaran dalam proses belajar mengajar di SMA/MA/SMK. Oleh karena itu, penanganan untuk siswa jenjang SMA/MA/SMK membutuhkan usaha dan perhatian lebih, khususnya pada pemilihan metode pembelajaran dan kompetensi pedagogik yang dimiliki oleh guru, mengingat kriteria usia siswa (15-18 tahun) pada jenjang ini dapat dikatakan sebagai masa peralihan seorang anak menuju masa remaja atau dewasa.

\section{Research Methods}

Penelitian ini menggunakan metode penelitian kualitatif deskriptif. Metode penelitian kualitatif merupakan metode yang bersifat penemuan langsung dengan metode pengumpulan data melalui observasi, wawancara, dan dokumentasi. 
Tujuan penelitian ini adalah untuk mengetahui, mendeskripsikan atau menggambarkan penggunaan metode pembelajaran berdasarkan kompetensi pedagogik yang dimiliki guru secara apa adanya (Rusnawati, 2015).

Subjek pada penelitian ini yaitu guru SMA/MA/SMK di daerah Gresik, Pasuruan, Malang, Jombang, dan Bojonegoro. Dengan beberapa pertimbangan yaitu, minat belajar dan sikap siswa pada jenjang SMA/MA/SMK lebih antusias. Survei terhadap guru sejumlah tiga puluh satu orang, dengan rincian informan kunci sebagai berikut:

Tabel 1. Data Informan Kunci Penelitian Variasi Metode Pembelajaran sebagai Implementasi Kompetensi Pedagogik Guru

\begin{tabular}{ccc}
\hline No. & Jenjang & Jumlah Informan \\
\hline 1. & SMA & 21 \\
2. & MA & 2 \\
3. & SMK & 8 \\
\hline & Total & $\mathbf{3 1}$ \\
\hline
\end{tabular}

Data diperoleh dengan 3 cara yaitu: 1) observasi, 2) wawancara, dan 3) dokumentasi. Pengolahan data dengan triangulasi data. Triangulasi data merupakan teknik pengumpulan data menggunakan teknik yang berbeda-beda untuk mendapatkan data dari sumber data yang sama. Peneliti menggunakan teknik observasi partisipatif, wawancara mendalam, dan dokumentasi untuk sumber data yang sama secara serempak (Sugiyono, n.d.)

Pertama, kegiatan observasi dilakukan dengan cara meninjau proses belajar mengajar yang dilaksanakan menggunakan media zoom meeting dan WhatsApp Group. Peninjauan ini, dilakukan dengan cara peneliti ikut bergabung pada tautan zoom meeting selama proses pembelajaran berlangsung. Dari kegiatan ini, peneliti menyimak secara langsung bagaimana proses belajar mengajar.

Kedua, pengambilan data dengan cara wawancara dilakukan dengan seorang informan yang merupakan guru Bahasa Inggris di SMA Negeri 1 Sangkapura Kabupaten Gresik. Guru ini merupakan pengajar yang telah mengabdi sejak tahun 1993. Kegiatan wawancara dilakukan secara tatap muka oleh peneliti dengan informan. Pengajuan pertanyaan, disesuaikan dengan pedoman yang telah dibuat oleh peneliti sebelum melakukan kegiatan wawancara.

Ketiga, pengambilan data secara dokumentasi dilakukan dengan cara survei pada guru SMA/MA/SMK melalui google form. Penggunaan google form sebagai survei, dipilih karena penelitian ini dilakukan pada saat pandemi Covid-19. Peneliti memanfaatkan layanan google form sebagai jalan pintas pengumpulan data yang dibutuhkan dalam penelitian. Penggunaan google form akan mempermudah untuk mengumpulkan data dengan rapi dan real time. Selain itu, peneliti hanya mengirimkan link kepada informan tanpa bertemu secara tatap muka. Sehingga, pemilihan google form sebagai survei dianggap paling efektif untuk meminimalisir penyebaran Covid-19 pada saat itu. Berikut adalah laman google form survei penelitian Variasi Metode Pembelajaran sebagai Implementasi Kompetensi Pedagogik Guru:

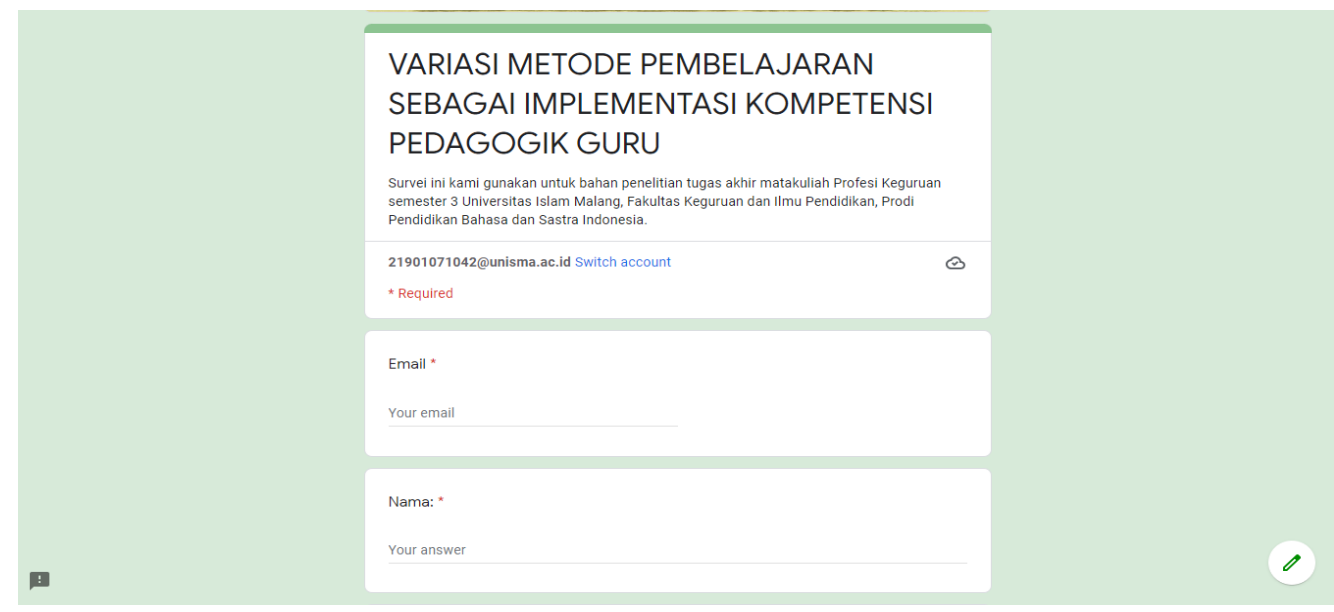

Gambar 1. Laman Google Form pertanyaan survei penelitian Variasi Metode Pembelajaran sebagai Implementasi Kompetensi Pedagogik Guru. Sumber: Hasil penelitian Variasi Metode Pembelajaran sebagai Implementasi Kompetensi Pedagogik Guru 
Hasil dari pengambilan data dalam penelitian ini, kemudian ditransformasikan ke dalam bentuk deskripsi pembahasan. Dalam deskripsi pembahasan, akan dijabarkan pemilihan metode pembelajaran yang sering digunakan oleh guru di SMA/MA/SMK. Selain itu akan dibahas pula alasan mendasar mengapa guru memilih metode pembelajaran tersebut. Analisis ini, akan dikelompokkan sesuai dengan mata pelajaran dari setiap guru di SMA/MA/SMK. Dari alasan tersebut, dapat diketahui kompetensi pedagogik yang dimiliki oleh seorang guru.

\section{Results and Discussion}

Penelitian yang dilakukan oleh Nasution (2018) yang berjudul "Penggunaan Metode Pembelajaran dalam Peningkatan Hasil Belajar Siswa" berfokus pada penggunaan metode pembelajaran meningkatkan hasil belajar siswa (Nasution, 2018). Hasil dari penelitian ini adalah hasil belajar setiap siswa dapat ditingkatkan dengan cara pemilihan metode pembelajaran yang tepat dan baik oleh guru pada proses belajar mengajar di sekolah. Perbedaan dari penelitian yang dilakukan oleh peneliti adalah implementasi kompetensi pedagogik yang dimiliki guru dalam pemilihan metode pembelajaran. Pemilihan metode pembelajaran yang dilakukan oleh seorang guru, berkesinambungan dengan salah satu kompetensi yang harus dimiliki yaitu kompetensi pedagogik guru.

Suhandi, dkk (2013) dalam penelitiannya yang berjudul "Efektivitas Penggunaan Metode Diskusi pada Mata Pelajaran Sosiologi di SMAN 2 Sungai Ambawang", memperoleh data bahwa penggunaan metode diskusi pada mata pelajaran Sosiologi di SMAN 2 Ambawang sudah efektif (Suhandi et al., 2013). Hal ini menunjukkan bahwa guru pengampu mata pelajaran, sudah menerapkan metode diskusi dengan baik. Guru dapat memanajemen kelas sebagai implementasi kompetensi pedagogik guru. Penelitian Suhandi, dkk (2013), hanya berfokus pada metode pembelajaran diskusi. Namun, pada penelitian ini metode pembelajaran yang dibahas bersifat umum (universal).

Penelitian yang berjudul "Penggunaan Metode Drill dalam Pembelajaran Matematika" yang dilakukan oleh Wahyuni (2016), menjelaskan bahwa mata pelajaran Matematika diterapkan dengan metode latihan (drill) karena dapat meningkatkan keaktifan dan perhatian siswa dalam proses pembelajaran matematika serta siswa dapat termotivasi dalam belajar (Wahyuni, 2016). Adanya metode tersebut membuat siswa lebih terlatih menghadapi berbagai macam model soal matematika, siswa lebih bersemangat dalam mempelajari materi yang diajarkan oleh guru. Hal ini menunjukan bahwa guru sudah mengimplementasi kompetensi pedagogiknya. Perbedaan dari penelitian yang dilakukan oleh peneliti adalah hasil data penelitian tentang alasan penggunaan metode pembelajaran, lebih bervariasi. Sebab, perolehan data pada guru mata pelajaran Matematika dalam penelitian ini tidak hanya menggunakan metode drill, namun juga menggunakan metode ceramah dan diskusi.

Dari hasil penelitian survei penggunaan metode pembelajaran pada guru SMA/MA/SMK melalui google form, peneliti mendapatkan tiga puluh satu informan dengan jangka waktu selama dua hari yang tercatat dari tanggal 28 Desember 2020 s/d 29 Desember 2020. Link google form disebarkan kepada guru SMA/MA/SMK melalui aplikasi whatsapp. Dari tiga puluh satu informan tersebut, guru yang paling dominan adalah guru SMAN 1 Sangkapura. Sekolah Menengah Atas ini merupakan sekolah satu-satunya yang menyandang sebagai SMA Negeri di Pulau Bawean, Kabupaten Gresik.

\section{Metode pembelajaran yang sering digunakan : 31 responses}
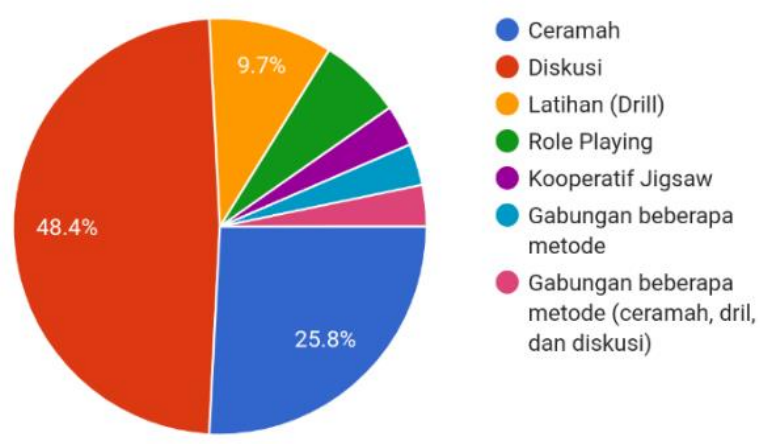

Gambar 2. Diagram lingkaran penggunaan metode pembelajaran guru di SMA/MA/SMK. Sumber: Hasil penelitian Variasi Metode Pembelajaran sebagai Implementasi Kompetensi Pedagogik Guru 
Gambar 2 menunjukkan bahwa, 15 guru menggunakan metode pembelajaran diskusi dengan persentase 48,4\%, selanjutnya 8 guru memilih menggunakan metode pembelajaran ceramah, dengan persentase 25,8\%. Kemudian, 3 guru memilih metode latihan $($ drill $)$ dengan persentase $9,7 \%$, dan sisanya menggunakan metode pembelajaran yang jarang digunakan yaitu role playing, kooperatif jigsaw, serta ada juga seorang guru yang menggunakan metode pembelajaran campuran yaitu dengan mencampurkan metode ceramah, diskusi, dan latihan (drill) untuk proses belajar mengajarnya. Pemilihan metode pembelajaran seorang guru, tentunya didasari oleh alasan.

Dari tiga puluh satu informan yang paling sering atau dominan adalah metode pembelajaran diskusi. Pemilihan metode pembelajaran ini, diperkuat dengan beberapa alasan yang mendasari guru tersebut. Alasan tersebut adalah guru lebih mengutamakan interaksi antar individu satu dengan individu yang lain atau antara siswa satu dengan siswa yang lainnya. Sehingga dari metode pembelajaran diskusi, diharapkan dapat merangsang daya pikir siswa untuk berani menyampaikan pendapatnya.

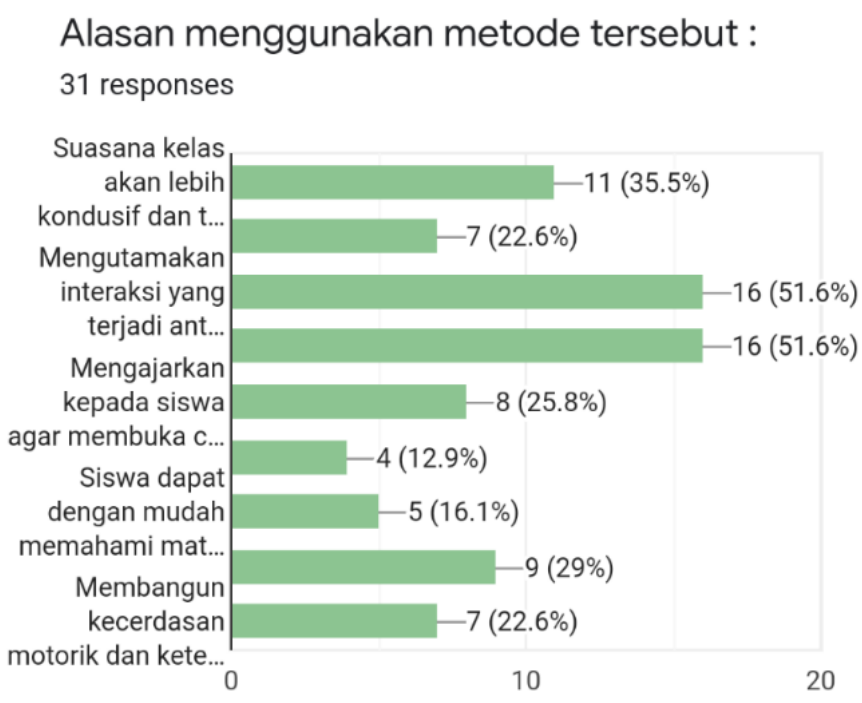

Gambar 3. Diagram batang alasan penggunaan metode pembelajaran guru di SMA/MA/SMK.

Sumber : Hasil penelitian Variasi Metode Pembelajaran sebagai Implementasi Kompetensi Pedagogik Guru

Menurut informan kunci yang merupakan guru Bahasa Inggris di SMAN 1 Sangkapura, menyatakan bahwa penggunaan metode pembelajaran yang digunakan ialah menggabungkan beberapa metode pembelajaran dengan cara mencampurkan metode ceramah, latihan (drill), dan diskusi. Informan, menggunakan metode pembelajaran $d r i l l$ pada pembelajaran yang berfokus pada ketatabahasaan, seperti grammar dan tenses. Metode diskusi biasanya digunakan saat pembelajaran yang membutuhkan reading skill seperti exposition text, report text, dan description text. Metode ceramah digunakan sebagai pengantar pembelajaran dan untuk penyampaian materi yang bersifat teoritis. Kemudian, informan menambahkan metode pembelajaran role playing untuk pembelajaran yang berhubungan dengan transactional and interpersonal text, seperti asking and giving direction, expressing thanks, dan introduction.

Dari pernyataan informan kunci, dapat diketahui bahwa informan merupakan guru yang kompeten karena dapat memanajemeni kelasnya dalam pembelajaran. Sebab, informan mampu memilih metode pembelajaran yang tepat untuk siswanya dalam proses belajar mengajar. Dari hasil wawancara dengan informan kunci, dapat diketahui bahwa pemilihan metode pembelajaran berhubungan dengan materi pembelajaran yang akan disampaikan guru kepada siswa. Sehingga dapat disimpulkan bahwa pemilihan metode pembelajaran berhubungan dengan mata pelajaran apa yang diampu oleh guru tersebut.

Tabel 2 merupakan tabel penggunaan metode pembelajaran guru sesuai mata pelajaran yang diampu berdasarkan kompetensi pedagogik yang dimilikinya. Dari tabel 2 dapat diketahui bahwa lima guru bahasa Indonesia menggunakan metode pembelajaran diskusi. Kelima guru bahasa Indonesia tersebut memilih metode pembelajaran diskusi, karena mata pelajaran bahasa Indonesia merupakan ilmu yang membutuhkan dan mengutamakan kegiatan berdiskusi yaitu bertukar pikiran, sehingga interaksi dengan setiap individu atau sangat penting guna mendorong siswa agar berani menyampaikan gagasan atau pendapatnya. 
Tabel 2. Data Hasil Survei Metode Pembelajaran Berdasarkan Mata Pelajaran yang Diampu oleh Guru SMA/MA/SMK.

\begin{tabular}{|c|c|c|c|c|c|c|c|c|}
\hline \multirow[t]{2}{*}{ No. } & \multirow[t]{2}{*}{ Mata Pelajaran } & \multirow[t]{2}{*}{ Jumlah } & \multicolumn{6}{|c|}{ Metode Pembelajaran } \\
\hline & & & Ceramah & Diskusi & Drill & $\begin{array}{c}\text { Role } \\
\text { Playing }\end{array}$ & $\begin{array}{c}\text { Kooperatif } \\
\text { Jigsaw }\end{array}$ & Gabungan \\
\hline 1. & $\begin{array}{l}\text { Bahasa } \\
\text { Indonesia }\end{array}$ & 5 & & $\checkmark \checkmark \checkmark \checkmark \checkmark$ & & & & \\
\hline 2. & Matematika & 3 & $\checkmark$ & $\checkmark$ & $\checkmark$ & & & \\
\hline 3. & Kimia & 2 & $\checkmark$ & $\checkmark$ & & & & \\
\hline 4. & Bahasa Inggris & 5 & $\checkmark$ & & $\checkmark$ & $\checkmark \checkmark$ & & $\checkmark$ \\
\hline 5. & Sejarah & 3 & $\checkmark \checkmark$ & $\checkmark$ & & & & \\
\hline 6. & Ekonomi & 3 & $\checkmark$ & $\checkmark \checkmark$ & & & & \\
\hline 7. & Penjaskes & 2 & & & $\checkmark$ & & $\checkmark$ & \\
\hline 8. & PPKn & 3 & $\checkmark$ & $\checkmark \checkmark$ & & & & \\
\hline 9. & Fisika & 3 & & $\checkmark \checkmark \checkmark$ & & & & \\
\hline 10 & Sosiologi & 1 & $\checkmark$ & & & & & \\
\hline 11. & Biologi & 1 & & & & & & $\checkmark$ \\
\hline
\end{tabular}

Sumber: Hasil Penelitian Variasi Metode Pembelajaran sebagai Implementasi Kompetensi Pedagogik Guru

Pada mata pelajaran Matematika, terdapat tiga guru yang menggunakan metode pembelajaran berbeda. Guru matematika pertama menggunakan metode diskusi, guru matematika kedua menggunakan metode ceramah, dan guru matematika ketiga menggunakan metode latihan (drill). Mata pelajaran Matematika membutuhkan keterlibatan siswa untuk lebih aktif berpikir dan memahami materi. Sebab, Matematika merupakan ilmu murni dan salah satu ilmu sains paling dasar yang membutuhkan latihan soal dan kegiatan berdiskusi untuk menemukan jawaban yang real dan alternatif pemecahan suatu masalah.

Mata pelajaran Kimia terdapat dua guru yang menggunakan metode pembelajaran berbeda dalam proses pembelajaran. Guru kimia pertama menggunakan metode diskusi, sedangkan guru kimia kedua menggunakan metode ceramah. Kimia adalah salah satu mata pelajaran yang melibatkan siswa untuk lebih aktif berpikir dan memahami materi. Sebab, Kimia merupakan salah satu ilmu sains paling dasar yang membutuhkan latihan soal dan kegiatan berdiskusi untuk menemukan jawaban yang riil.

Dari hasil survei, terdapat lima guru mata pelajaran Bahasa Inggris yang dua diantaranya menggunakan metode role playing, dan tiga lainnya menggunakan metode pembelajaran yang berbeda. Guru Bahasa Inggris pertama menggunakan metode ceramah, guru bahasa inggris kedua dan ketiga menggunakan metode role playing, guru Bahasa Inggris keempat menggunakan gabungan dari beberapa metode pembelajaran, dan guru Bahasa Inggris kelima menggunakan metode latihan (drill). Mata pelajaran bahasa Inggris membutuhkan lebih banyak interaksi antar siswa. Karena materi dalam mata pelajaran bahasa Inggris lebih berfokus pada ketatabahasaan dan jenis-jenis teks.

Pada mata pelajaran Sejarah, terdapat tiga guru sejarah yang menggunakan metode ceramah dan dua lainnya menggunakan metode diskusi. Guru sejarah pertama dan kedua menggunakan metode ceramah, sedangkan guru sejarah ketiga menggunakan metode diskusi. Mata pelajaran Sejarah membutuhkan interaksi antar siswa agar membangkitkan semangat belajar siswa. Guru dapat mengajak siswa untuk bermain peran dari suatu kejadian sejarah agar minat belajar siswa meningkat dalam proses pembelajaran mata pelajaran Sejarah.

Pada mata pelajaran Ekonomi terdapat tiga guru yang dua diantaranya menggunakan metode diskusi, dan sisanya menggunakan metode ceramah. Guru ekonomi pertama, kedua, dan ketiga menggunakan metode diskusi, sedangkan guru ekonomi keempat menggunakan metode ceramah. Ekonomi merupakan mata pelajaran yang membutuhkan kegiatan latihan mengerjakan soal, karena pada mata pelajaran ini terdapat materi yang berhubungan dengan menghitung seperti konsep dasar menghitung perbukuan besar dalam sub bab akuntansi dan menghitung persentase pajak pada sub bab administrasi pajak mata pelajaran ekonomi.

Dari hasil survei, ada dua guru mata pelajaran Penjaskes. Kedua guru Penjaskes ini, menggunakan metode pembelajaran berbeda. Guru penjaskes pertama menggunakan metode latihan (drill) dan guru penjaskes kedua menggunakan metode kooperatif jigsaw. Mata pelajaran Penjaskes lebih banyak kegiatan praktik daripada teori. Penggunaan metode latihan ( rill) berguna untuk melatih siswa menyempurnakan praktiknya dan penggunaan metode kooperatif jigsaw dilakukan dengan cara salah satu siswa diminta untuk melakukan praktik di depan temannya, tujuannya untuk membantu teman lainnya yang belum bisa. 
Dari hasil survei, terdapat tiga guru PPKn yang menggunakan metode pembelajaran berbeda. Guru PPKn pertama dan kedua menggunakan metode diskusi, sedangkan PPKn ketiga menggunakan metode ceramah. Mata pelajaran PPKn merupakan mata pelajaran yang memiliki materi yang dominan dengan teori kewarganegaraan. Penggunaan metode diskusi akan membangkitkan semangat siswa saat proses pembelajaran.

Pada mata pelajaran Fisika, terdapat tiga guru yang menggunakan metode pembelajaran sama yaitu diskusi. Mata pelajaran Fisika merupakan salah satu ilmu sains paling dasar sehingga diperlukan latihan soal dan kegiatan diskusi dan latihan soal agar siswa memahami materi dengan mudah dan siswa dapat menemukan jawaban atau alternatif pemecahan suatu masalah yang benar.

Satu-satunya guru Sosiologi menggunakan metode pembelajaran ceramah dalam proses pembelajaran. Mata pelajaran sosiologi merupakan ilmu yang mempelajari tentang sosial masyarakat, dimana dalam mata pelajaran ini lebih dominan teori tentang masyarakat. Penggunaan metode pembelajaran mata pelajaran sosiologi, dibutuhkan kegiatan interaksi antar siswa. Sebab, apabila hanya menggunakan metode ceramah, siswa akan pasif dalam pembelajaran karena merasa monoton dan cepat bosan.

Dari hasil survei, terdapat seorang guru Biologi yang menggunakan metode pembelajaran gabungan. Mata pelajaran biologi membutuhkan metode pembelajaran yang melibatkan interaksi antar siswa. Pada mata pelajaran ini banyak kegiatan di laboratorium yang mengharuskan siswa bekerja sama dengan siswa lain saat praktik.

\section{Conclusion}

Adapun kesimpulan yang dapat diambil dari hasil penelitian penggunaan metode pembelajaran guru SMA/MA/SMK adalah sebagai berikut:

1) Penggunaan metode pembelajaran yang sering digunakan guru adalah metode diskusi. Penggunaan metode diskusi dominan digunakan oleh guru mata pelajaran bahasa Indonesia.

2) Penggunaan metode pembelajaran diskusi digunakan guru karena mengutamakan interaksi yang terjadi antar individu sehingga merangsang daya pikir siswa untuk berani menyampaikan pendapatnya.

3) Mata pelajaran yang teoritis seperti matematika, fisika, kimia, ekonomi, dan biologi memerlukan penjelasan yang banyak sehingga tepat apabila menggunakan metode ceramah. Namun, interaksi antar siswa dan latihanlatihan soal juga sangat diperlukan. Sehingga, metode ceramah perlu berkolaborasi dengan metode diskusi dan latihan (drill) untuk mencapai tujuan pembelajaran yang baik untuk siswa.

4) Mata pelajaran yang memerlukan interaksi antar siswa seperti bahasa Indonesia, bahasa Inggris, sejarah, sosiologi, dan PPKn tepat apabila menggunakan metode diskusi. Sebab, mata pelajaran ini, dibutuhkan aktivitas bertukar pikiran dengan sesama teman agar dapat menyelesaikan permasalahan yang ada.

\section{References}

Aditya, D. Y. (2016). Pengaruh Penerapan Metode Pembelajaran Resitasi terhadap Hasil Belajar Matematika Siswa. SAP (Susunan Artikel Pendidikan), 1(2).

Isjoni, H. (2014). Cooperative Learning, Efektifitas Pembelajaran Kelompok.

Junita, J., \& Siregar, M. (2018). Penerapan Metode Pembelajaran Diskusi dalam Peningkatan Prestasi Belajar pada Kompetensi Dasar Menjelaskan Makna Kedaulatan Rakyat Siswa Kelas VIII SMP Negeri 2 Kota Pinang Kabupaten Labuhanbatu Selatan Tahun Pelajaran 2014/2015. CIVITAS (JURNAL PEMBELAJARAN DAN ILMU CIVIC), 4(1), 36-45.

Nasution, M. K. (2018). Penggunaan metode pembelajaran dalam peningkatan hasil belajar siswa. Studia Didaktika, 11(01), 9-16.

Pratiwi, R. A. (2021). MAKALAH-PENERAPAN METODE CERAMAH DAN DISKUSI SELAMA PEMBELAJARAN ONLINE.

Rusman, D., \& Pd, M. (2012). Model-model pembelajaran. Raja Grafindo, Jakarta.

Rusnawati, R. (2015). Kompetensi Pedagogik Guru Dalam Memotivasi Minat Belajar Siswapada SMAN 1 Leupung. Intelektualita, 3(2). 
Sari, I. N. (2020). BAB IV PRAKTIK MANAJEMEN PENDIDIKAN. Dunia Pendidikan Indonesia Menuju Era Revolusi 4.0, 79.

Sugiyono, P. (n.d.). Dr.,(2007), Metode Penelitian Pendidikan (Pendekatan Kuantitatif, Kualitatif, dan R\&D). Bandung: CV. Alfabeta.

Suhandi, D. Y., Ibrahim, M. Y., \& Budjang, G. (2013). Efektivitas penggunaan metode diskusi pada mata pelajaran sosiologi di SMA Negeri 2 Sungai Ambawang. Jurnal Pendidikan Dan Pembelajaran Khatulistiwa, 2(9).

Sumarsono, S., Subandi, S., \& Imam, S. (2021). The Role of School Principal in Learning Islamic Religious Education in SD Negeri 01 Kayu Batugunung Labuhan Way Kanan. Bulletin of Pedagogical Research, 1(1), 54-69.

Wahyuni, N. (2016). Penggunaan Metode Drill Dalam Pembelajaran Matematika. Prosiding, 2(1).

Wibowo, A. (2012). Menjadi guru berkarakter: strategi membangun kompetensi \& karakter guru. Pustaka Pelajar. 